\title{
JERZY SŁYK
}

Uniwersytet Kardynała Stefana Wyszyńskiego

\section{PSYCHOLOGICZNE UWARUNKOWANIA ZACHOWAŃ DZIECI WYRZAZDZAJACCYCH SZKODE A ODPOWIEDZIALNOŚĆ RODZICÓW Z TYTUŁU NADZORU NAD NIMI}

W rozważaniach nad problematyką odpowiedzialności cywilnej rodziców za szkodę wyrządzoną przez ich dziecko na pierwszy plan wysuwa się zagadnienie zależności między procesem wychowywania dziecka przez rodziców, a jego zachowaniami. Problem ten występuje przede wszystkim w przypadku odpowiedzialności rodziców na podstawie art. 415 k.c., a więc wtedy, gdy konieczne jest wykazanie związku przyczynowego między działaniami rodziców, podejmowanymi w ramach procesu wychowawczego, a wyrządzeniem szkody przez dziecko. Jednakże również prawidłowa wykładnia pojęcia nadzoru, którym posługuje się art. 427 k.c., musi opierać się o ustalenia dotyczące tego, jak ścisły jest ów związek i na czym polega. Ustawodawca wprowadza do aktów normatywnych klauzule generalne i pozostawia pewien „luz interpretacyjny” przepisów po to, aby ich wykładnia mogła przebiegać w zgodzie z funkcją społeczną poszczególnych unormowań. Wydaje się, iż przyjmowana obecnie wykładnia przepisów o odpowiedzialności rodziców za szkodę wyrządzoną przez ich dziecko jest oparta na fikcyjnym założeniu o znikomym wpływie rodziców na zachowanie ich dzieci, skoro pojęcie nadzoru, użyte w art. 427 k.c., jest najczęściej rozumiane w wąskim znaczeniu, odpowiadającym wykonywaniu bieżącej pieczy, nie zaś podejmowania wszelkich działań 
determinujących zachowanie dziecka ${ }^{1}$. Wykazanie ścisłego związku i stałych zależności między postępowaniem rodziców, a zachowaniem ich dzieci będzie przemawiać za włączeniem w ramy pojęcia nadzoru w rozumieniu art. 427 k.c. również wychowywania dziecka. Zagadnienia te nabierają szczególnej wagi w odniesieniu do rodzin rozbitych, a więc zwłaszcza $\mathrm{w}$ przypadku rozwodu rodziców i w innych sytuacjach, które powodują, iż władza rodzicielska nie jest w pełni wykonywana przez oboje rodziców, na przykład wtedy, gdy rodzice nigdy nie byli małżeństwem, żyją w rozłączeniu, a wykonywanie bieżącej pieczy powierzone jest jednemu z nich.

W zasadzie samo przeciętne doświadczenie życiowe pozwala na sformułowanie tezy, że oczywisty jest wpływ działań wychowawczych rodziców na dziecko, jednakże pewne czynniki, takie jak np. jego upośledzenie, czy wpływ środowiska koleżeńskiego, w którym ono przebywa, mogą utrudniać ocenę konkretnego stanu faktycznego. Rozważenia wymaga również ocena czynników o charakterze biologicznym. Dlatego też warto odnotować pytanie, jakiego rodzaju błędne działania rodziców wywołują skutki w postaci określonego postępowania dziecka. Dopiero odpowiedź na tak postawione pytanie pozwoli rozstrzygnąć zagadnienia prawne związane z odpowiedzialnością cywilną rodziców w przypadku zaniedbania obowiązku właściwego wychowania dziecka.

Jednym $\mathrm{z}$ fundamentalnych problemów psychologii dziecka, jest określenie relacji, w jakich pozostają czynniki zewnętrzne (wpływ środowiska, wychowanie) i wewnętrzne (uwarunkowania biologiczne), mające wpływ na rozwój dziecka ${ }^{2}$. Jakkolwiek dające się wyróżnić w nauce psychologii koncepcje teoretyczne różnią się między soba, to jednak wszystkie, jako niezmiernie istotne dla rozwoju dzie-

\footnotetext{
${ }^{1}$ Por. np.: E. Łętowska, Przyczynienie się małoletniego do wyrzqdzenia szkody, «NP» 21.2 (1965), s. 138; A. SzPUNAR, Odpowiedzialność osób zobowiazanych do nadzoru, Warszawa 1978, s. 123.

${ }^{2}$ R. Vasta, M. M. Haiti, S.A. Miller, Psychologia dziecka, Warszawa 2004, s. 39.; P. G. Zimbardo, Psychologia i życie, Warszawa 2005, s. 155.
} 
cka czynniki, wskazują oddziaływania zewnętrzne ${ }^{3}$. Jako historyczną można wskazać koncepcję czysto natywistyczną Jana Jakuba Rousseau, według której rozwój człowieka wynika wyłącznie z wrodzonych procesów decydujących w przewidywalny sposób o określonych zachowaniach ${ }^{4}$. Obecnie przyjmuje się, iż o rozwoju psychicznym dziecka decydują zarówno czynniki dziedziczne, jak i środowiskowe ${ }^{5}$, przy czym tymi ostatnimi można wpływać na uwarunkowania genetyczne ${ }^{6}$, które nie muszą determinować rozwoju dziecka w sposób bezwzględny.

Wskazane wyżej problemy są przedmiotem badań psychologów w szczególności w ramach działów tzw. psychologii wychowawczej ${ }^{7}$

${ }^{3}$ Wyróżnia się kierunek poznawczo-rozwojowy, kierunek akcentujący rolę uczenia się oraz podejście etologiczne, tj. badanie rozwoju z perspektywy ewolucyjnej (szerzej: R. Vasta, M. M. Haiti, S.A. Miller, op. cit., s. 48-69).

${ }^{4}$ R. Vasta, M. M. Haiti, S.A. Miller, op. cit., s. 28.

${ }^{5}$ P.G. Zimbardo, op. cit., s. 157.

${ }^{6} \mathrm{~Np}$. dopasowanie właściwej diety obciążonych genetycznie noworodków pozwala uniknąć skutków występującej u nich wady genetycznej hamującej rozwój intelektualny. Por. P.G. ZimBARdo, op. cit., s. 150.

${ }^{7}$ M. Przetacznik-Gierowska, [w:] M. Przetacznik-Gierowska, G. MakielŁo-Jarża, Psychologia rozwojowa $i$ wychowawcza wieku dziecięcego, Warszawa 1985, s. 275-277 wskazuje, iż w ramach psychologii wychowawczej można wyodrębnić psychologię nauczania i wychowania. Nie jest przy tym możliwe oddzielenie psychologii wychowawczej od innych gałęzi psychologii, które są z nią ściśle powiązane. Podstawą dla psychologii nauczania jest psychologia uczenia się, a dla psychologii wychowania - psychologia osobowości. Psychologia nauczania zajmuje się nauczaniem rozumianym jako ,kierowanie uczeniem się innych osób, przybierającym różne formy zależnie od wieku”. Oddziaływania wychowawcze ,zmierzają do wywołania w psychice ludzkiej względnie trwałych zmian, ukierunkowanych progresywnie (...) tak, by [rozwój jednostki] przebiegał zgodnie z określonymi celami wychowania". Psychologia wychowawcza zajmuje się problemami psychologicznej struktury tych oddziaływań, sposobami oddziaływań wychowawczych, takimi jak modelowanie zachowań wychowanka, wzmacnianie ich za pomocą nagród i kar, stawiania zadań i wymagań, analizą środowisk wychowawczych zarówno naturalnych (rodzina, grupa rówieśnicza), jak i instytucjonalnych (żłobek, przedszkole, szkoła, zakład wychowawczy). Por. też M. Przetacznikowa, Z. WŁodarski, Psychologia wychowawcza, Warszawa 1986, s. 17-18. 
i rozwojowej ${ }^{8}$. W niniejszym opracowaniu nie jest możliwe szczegółowe omówienie całej problematyki z tego zakresu, jednakże - oprócz rozważań prawnych - niezbędne jest również przybliżenie niektórych problemów, którymi zajmuje się psychologia wychowawcza, a które wymagają uwzględnienia w procesie stosowania prawa. Zostaną zatem przedstawione wyniki niektórych badań oraz teorie naukowe wyjaśniające związek między wychowawczym oddziaływaniem na dziecko, a jego rozwojem.

W pierwszej kolejności, warto zwrócić uwagę na wyniki niektórych badań nad wpływem deprywacji ${ }^{9}$ emocjonalnej na prawidłowość rozwoju dzieci.

W prowadzonych w latach 1935-43 badaniach nad hospitalizowanymi niemowlętami, Margaret Ribble stwierdziła u nich zaburzenia fizjologiczne, co doprowadziło do sformułowania tezy, iż brak normalnej interakcji między matką a dzieckiem może prowadzić u tego ostatniego do zaburzeń o charakterze biologicznym i psychologicznym ${ }^{10}$.

Innym ciekawym eksperymentem były badania przeprowadzone po zakończeniu II wojny światowej w sierocińcach niemieckich. Badania prowadzono w dwóch sierocińcach. Przez pierwsze 26 tygodni dzieci w obu sierocińcach otrzymywały takie same racje żywnościowe. W sierocińcu, w którym dzieci miały łagodną i czułą opiekunkę przyrost ich wagi był większy niż tam, gdzie pieczę nad dziećmi sprawowała osoba surowa. Następnie opiekunki dzieci zamieniono, a racje żywnościowe zwiększono w tym sierocińcu, w którym znalazła się przełożona surowa. Mimo to nadal większy przyrost wagi odnotowa-

${ }^{8}$ Wśród jej zadań wymienia się m.in. poszukiwanie odpowiedzi na pytania o przebieg i charakterystykę procesu rozwoju psychicznego dziecka, o właściwości psychiczne dziecka w różnych etapach jego życia oraz o to, jakie warunki i czynniki kształtują stopniowo czynności dziecka i coraz bardziej sensowną jego działalność, a także, jakie prawa rządzą jego rozwojem, czyli przekształcaniem psychiki i świadomości. M. ŻEBrowska, Psychologia rozwojowa dzieci i młodzieży, Warszawa 1975, s. 16.

${ }^{9}$ Por. P.G. ZimBardo, op. cit., s. 664, według którego deprywacja to brak (lub pozbawienie) bodźców umożliwiających zaspokojenie potrzeb lub czegoś niezbędnego do biologicznego lub psychicznego funkcjonowania.

${ }^{10}$ P.G. Zimbardo, op. cit., s. 14. 
no w sierocińcu, w którym znalazła się łagodna przełożona ${ }^{11}$. Przykład ten przytoczono, ponieważ uwidacznia on przewagę czynnika psychologicznego w rozwoju dzieci nad czynnikiem biologicznym i to nawet w zakresie ich rozwoju fizycznego.

Rene Spitz i Katherine Wolf, analizując w 1946 r. historie 91 porzuconych niemowląt, uzyskali wyniki mówiące o występowaniu wśród tych dzieci niepokoju, przygnębienia, opóźnienia rozwoju fizycznego, bezsenności, odrętwienia, patologicznej niedowagi oraz wysokiej śmiertelności ${ }^{12}$.

Z kolei Lytt Gardner w 1972 r. przeprowadził badania nad dziećmi $z$ rodzin obarczonych zobojętnieniem emocjonalnym i brakiem normalnej więzi uczuciowej między rodzicami a dziećmi. Wykazano, iż ich upośledzenie fizyczne (niski wzrost, niedowaga, opóźniony wzrost kości) oraz zaburzenia w rozwoju intelektualnym i kształtowaniu osobowości mają swoje źródło w długotrwałej deprywacji emocjonalnej we wczesnym okresie życia ${ }^{13}$. Wskazano również na więź fizjologiczną wyjaśniającą obserwowane zjawiska, polegającą na oddziaływaniu części mózgu zwanej podwzgórzem, odpowiedzialnej za wzbudzanie emocjonalne $\mathrm{z}$ przysadką mózgową, wydzielającą hormony wzrostowe ${ }^{14}$.

Przytoczone powyżej przykłady wyników badań pozwalają sformułować tezę, iż zasadnicze znaczenie w wychowaniu dziecka posiada właściwe wykonywanie swoich funkcji przez matkę i ojca, jako osób pozostających $\mathrm{z}$ dzieckiem $\mathrm{w}$ najściślejszym kontakcie. Oczywiście charakter tych ról podlega daleko idącym przeobrażeniom, wraz z przemianami społecznymi, kulturowymi i obyczajowymi. Wskazuje się na przeciwstawne modele rodziny, warunkujące pełnione przez małżonków role, takie jak model rodziny patriarchalnej i dominujący w czasach współczesnych w naszym regionie kulturowym - rodzi-

\footnotetext{
${ }^{11}$ Badania te prezentuje P.G. ZimBARDo, op. cit., s. 14.

12 P.G. Zimbardo, op. cit., s. 14.

${ }^{13}$ L. Gardner, Deprivation dwarfism, «Scientific American» 227 (1972), s. 76-82.

${ }^{14}$ L. GARDNER, op. cit., s. 81.
} 
ny egalitarnej ${ }^{15}$. Jakkolwiek w rodzinach współczesnych role matki i ojca zbliżyły się do siebie, to jednak zwraca się uwagę na pewne cechy różnicujące zadania matki i ojca, które determinują rozwój emocjonalny dziecka. Spośród elementów roli matki, jako najważniejsze, wymienia się odpowiedzialność i opiekuńczość ${ }^{16}$. Kobiety wychowywane przez oschłe matki, bądź bez udziału matek, mogą mieć trudności z przyswojeniem właściwych wzorów zachowania kobiety-matki ${ }^{17}$. Ze względu na przedmiot niniejszego opracowania, szczególnie istotna - jako czynnik dyscyplinujący - jest rola ojca w procesie wychowawczym dziecka. Uświadomienie w środowisku naukowym jego roli wychowawczej mogło nastapić po II wojnie światowej, która stworzyła sytuację pozwalająca na poddanie badaniom tego wpływu poprzez analizę rozwoju dzieci, które były pozbawione ojca - ze względu na jego powołanie do wojska - od momentu urodzenia do zakończenia wojny ${ }^{18}$. Porównanie tego typu sytuacji, z przypadkami dzieci wychowywanych w rodzinach pełnych wykazało u tych pierwszych szereg zaburzeń w zachowaniu, lękliwość, drażliwość i wrogie nastawienie do innych dzieci, przy czym brak ojca wywierał szczególnie niekorzystny wpływ na rozwój chłopców, którzy wykazywali niedojrzałość społeczną oraz zaburzenia w zachowaniu w szkole ${ }^{19}$. U dziewcząt brak ojca może powodować niemożność późniejszego emocjonalnego związania się z partnerem ${ }^{20}$.

O przebiegu procesu wychowawczego w środowisku rodzinnym decyduje w ogromnej mierze przyjęcie określonych postaw rodziciel-

${ }^{15}$ G. Makiello-Jarża, [w:] M. Przetacznik-Gierowska, G. Makiello-Jarża, cit., S. 301-302.

${ }^{16}$ G. MAKIEllO-JARŻA, op. cit., s. 303.

${ }^{17}$ G. MAKIEllO-JARŻA, op. cit., s. 303.

${ }^{18}$ G. MAKIElŁO-JARŻA, op. cit., s. 304.

${ }^{19}$ G. MAKIElŁO-JARŻA, op. cit., s. 304.

${ }^{20}$ G. MakielŁo-JarŻa, op. cit., s. 305. Na temat roli ojca w życiu dziecka por. również W. StoJANowsKA, Władza rodzicielska pozamałżéskiego i rozwiedzionego ojca. Studium socjologiczno-prawne, Warszawa 2000, s. 17-20, oraz powołaną tam literaturę. 
skich $^{21}$ przez matkę i ojca. Zależności te są przedmiotem badań od wielu lat. Przykładowo, w 1945 r. stwierdzono związek między rodzajem postaw rodziców, a rozwojem intelektualnym ich dzieci ${ }^{22}$. Rozwój ten miał być pobudzany przez tzw. demokratyczny typ zachowania rodziców, a hamowany w przypadku zbytniego chronienia dziecka i nadmiernego rygoryzmu rodziców ${ }^{23}$. W szczególności, w wielu badaniach odnotowano wpływ postaw rodzicielskich na wyniki dziecka w nauce $^{24}$. Wykazano również, iż takie postawy rodziców jak brak akceptacji i unikanie kontaktu z dzieckiem wywołują silne pobudzenie do agre$\mathrm{sji}^{25}$, podobnie jak stosowanie kar cielesnych oraz straszenie dziecka ${ }^{26}$. Decydującym czynnikiem w procesie wychowania jest zatem stosunek uczuciowy rodziców do dziecka czyli to, co zostało wcześniej określone mianem postawy rodzicielskiej. Pozwala to na postawienie tezy o szerokim zakresie wpływu rodziców na zachowanie dzieci, co przeczy teoriom wiążącym rozwój osobowości przede wszystkim z czynnikiem biologicznym ${ }^{27}$.

${ }^{21}$ Por. M. ZIEMskA, Postawy rodzicielskie, Warszawa 1973, s. 33, według której postawa rodzicielska to nabyta struktura poznawczo-dążeniowo-afektywna, ukierunkowująca zachowanie się rodziców wobec dziecka, przy czym chodzi tu nie o krótkotrwale nastawienie, lecz o stałą w pewnym okresie komponentę emocjonalną, która dominuje w sposobie odnoszenia się do dziecka. Postawy rodzicielskiej w tym rozumieniu nie należy utożsamiać ze stosowaniem określonych metod wychowawczych (np. sankcji) przez rodziców - najważniejsze jest ich nastawienie emocjonalne. Stosowanie tych samych środków wychowawczych może dawać różne rezultaty przy różnych postawach emocjonalnych. Por. też. M. ZIEMSKA, Postawy rodzicielskie $i$ ich wptyw na osobowość dziecka, [w:] Rodzina i dziecko, red. M. ZIEMSKA, Warszawa 1986, s. 167.

${ }^{22}$ Por. badania omówione przez M. ZIEMSKA, Postawy rodzicielskie i ich wptyw na osobowość dziecka, cit., s. 160 i n.

${ }^{23}$ M. ZIEMSKA, Postawy rodzicielskie i ich wptyw, cit., s. 160 i n.

${ }^{24}$ M. ZIEMSKa, Postawy rodzicielskie $i$ ich wptyw, cit., s. 161-162.

${ }^{25}$ M. Ziemska, Postawy rodzicielskie i ich wptyw, cit., s. 163.

${ }^{26}$ M. ZIEMSKA, Postawy rodzicielskie i ich wplyw, cit., s. 166.

${ }^{27}$ Do takiego wniosku dochodzi w swoich badaniach M. ZIEMSKA, Postawy rodzicielskie i ich wptyw, cit., s. 160 i n. 
Właściwe zdefiniowanie postaw rodzicielskich pozwala - w sposób uporządkowany - określić skutki przyjęcia przez rodziców określonych modeli wychowawczych. I tak np. wg. L. Kannera można wyróżnić postawy: 1) akceptacji i uczucia, 2) jawnego odtrącenia, 3) perfekcjonizmu, oraz 4) nadmiernego chronienia ${ }^{28}$. Miałyby one u dziecka korelować - odpowiednio - z: 1) poczuciem bezpieczeństwa i prawidłowym rozwojem, 2) agresywnościa, wykolejeniem, zahamowaniem rozwoju uczuć wyższych, 3) frustracją i obsesjami, brakiem wiary we własne siły, 4) opóźnieniem dojrzałości i zależnością od matki. Typologii tej zarzucono jednak niepełność ${ }^{29}$. Jako przykład rozbudowanego modelu typizującego postawy rodzicielskie wskazać można zaproponowany przez E. S. Schaefera model zachowania macierzyńskiego $^{30}$, w którym wyróżniono aż czternaście możliwych postaw rodzicielskich, pogrupowanych według podobieństwa i zredukowanych do czterech najważniejszych. Jest to postawa oparta na miłości i przeciwna jej postawa oparta na wrogości wobec dziecka oraz postawa polegająca na przyznaniu dziecku szerokiej autonomii i odpowiadająca jej postawa przeciwna, w której przeważa element władzy nad dzieckiem $^{31}$.

Przejrzystą typologię postaw rodzicielskich przedstawiła M. Ziemska na podstawie badań klinicznych 283 rodzin $^{32}$. Punktem wyjścia dla jej rozważań było spostrzeżenie, iż źródłem niewłaściwych postaw rodzicielskich jest bądź nadmierny dystans uczuciowy w stosunku do dziecka, bądź nadmierna nad nim koncentracja ${ }^{33}$, przy czym

${ }^{28}$ Por. M. Ziemska, Postawy rodzicielskie, cit., s. 41-42.

${ }^{29}$ M. Ziemska, Postawy rodzicielskie, cit., s. 41-42.

${ }^{30}$ Por. M. ZIEMSKa, Postawy rodzicielskie, cit., s. 45.

${ }^{31}$ Również ten model został poddany krytyce, głównie ze względu na wadliwość opisanego „układu współrzędnych”. Z jednej strony przeciwstawieniu wrogości i miłości zarzucono nietrafność (przeciwieństwem miłości jest nienawiść), z drugiej wskazano, iż czynnik autonomii nie jest elementem stałym w rozwoju dziecka, a wzrasta wraz z jego wiekiem. Tak: M. ZIEMska, Postawy rodzicielskie, cit., s. 47.

${ }^{32}$ M. Ziemska, Postawy rodzicielskie, cit., s. 50 i n.

${ }^{33}$ M. ZIEMSKA, Postawy rodzicielskie, cit., s. s. 54. 
zaburzenia kontaktu z dzieckiem wiążą się również z takimi cechami zachowań rodziców jak dominacja bądź zbytnia uległość ${ }^{34}$.

Stosownie do poczynionych spostrzeżeń, autorka wyróżniła cztery postawy wywierające negatywny wpływ na dziecko i cztery im przeciwne, korzystnie oddziałujące na rozwój dziecka. Tak więc, jako negatywnie oddziałujące na dziecko, można wyróżnić postawy: odtrącająca, unikająca, nadmiernie wymagającą i nadmiernie chroniąca, a jako przeciwne im - odpowiednio: postawę akceptacji, współdziałania, uznania praw i rozumnej swobody ${ }^{35}$ :

Akceptacja polega na przyjęciu dziecka takim, jakim ono jest, wraz z jego osobistymi uzdolnieniami i ograniczeniami, co nie oznacza jednak aprobowania złych jego zachowań. Postawa odtrącająca wiąże się z dystansem uczuciowym rodziców wobec dziecka i dominacją. Występuje ona wtedy, gdy dziecko traktowane jest jako ciężar. Z odtrąceniem wiąże się nieokazywanie uczuć pozytywnych, dezaprobata, otwarta krytyka dziecka, podejście dyktatorskie. Współdziałanie wiąże się z zainteresowaniem rodziców różnymi przejawami aktywności dziecka. Przeciwna współdziałaniu postawa unikająca jest związana z obojętnością uczuciową rodziców wobec dziecka, brakiem przyjemności w obcowaniu z nim. Rodzice często starają się ukryć tę obojętność, obdarzając dziecko prezentami i stosując wobec niego ,liberalizm wychowawczy". Uznanie praw dziecka przez rodziców oznacza szacunek dla jego indywidualności i zezwolenie na aktywność dziecka ze świadomością odpowiedzialności za jego działania, przy czym wzajemne relacje i dyscyplina są osadzone na racjonalnych podstawach. Zaprzeczeniem takiego podejścia jest postawa nadmiernie wymagająca, przy której funkcjonowanie dziecka jest naginane do ,idealnego", wytworzonego przez rodziców wzorca, poprzez stawianie mu wygórowanych wymagań, nieprzyznawanie samodzielności, dążenie do nadmiernie przyspieszonego rozwoju. Dawanie dziecku rozumnej

${ }^{34}$ M.ZIEMSKa, Postawy rodzicielskie, cit., s. 55 uważa,żeuległość oznacza tu nie tylko uleganie przez rodziców zachciankom dziecka, ale również podporządkowanie źle rozumianym przez siebie potrzebom jego rozwoju.

${ }^{35}$ M. Ziemska, Postawy rodzicielskie, cit., s. 60. 
swobody oznacza kształtowanie jego relacji z rodzicami na zasadzie zaufania, stosownie do rozwoju dziecka, przy zachowaniu autorytetu i kontroli nad kierowaniem dziecka. Przeciwieństwem tego typu zachowań rodziców jest postawa nadmiernie chroniąca, związana z bezkrytycznym podejściem do dziecka, nadmierną opiekuńczością i pobłażliwością, ograniczaniem jego swobody ze względu na przesadne obawy o dziecko ${ }^{36}$.

Spójne i wyczerpujące ujęcie rodzajów postaw rodzicielskich, umożliwia wskazanie, jaki wpływ wywierają na dziecko poszczególne rodzaje negatywnych oddziaływań wychowawczych rodziców. Postawa odtrącająca wywołuje u dziecka cechy agresywności, nieposłuszeństwa, kłótliwości, kłamstwa, kradzieży, zachowania aspołeczne i antyspołeczne, bezradność, a przy nagłym odtrąceniu - reakcje nerwicowe $^{37}$. Unikanie kontaktu z dzieckiem może prowadzić do uniemożliwienia mu nabycia zdolności nawiązywania trwałych więzi uczuciowych, może sprzyjać wykształceniu nastawienia antagonistycznego do społeczeństwa i jego instytucji, niezdolności do obiektywnych ocen, poczucia prześladowania, niezdolności do wytrwałości i koncentracji w nauce, może również prowadzić do lżejszych objawów wykolejenia $^{38}$. W kontekście głównego tematu niniejszego opracowania wypada powtórzyć za M. Ziemską i szczególnie podkreślić, iż frustracja wywołana przez zaniedbanie lub odtrącenie dziecka, powoduje jego gniew i agresję, a dystans uczuciowy u starszych dzieci prowadzi do typu zachowania aspołecznego i antyspołecznego. W tych przypadkach - z punktu widzenia klinicznego - będziemy mieć do czynienia z dziećmi psychopatycznymi ${ }^{39}$. Sytuacje te będą ściśle odpowiadały

${ }^{36}$ Szersza charakterystyka wymienionych postaw: M. ZIEMSKA, Postawy rodzicielskie, cit., s. 57-64. Por. również TeJżE, Postawy rodzicielskie i ich wplyw, cit., s. $181 \mathrm{i} \mathrm{n.}$

${ }^{37}$ M. ZiEmsKa, Postawy rodzicielskie, cit., s. 66.

${ }^{38}$ M. Ziemska, Postawy rodzicielskie, cit., s. 66.

${ }^{39}$ M. ZIEMsKa, Postawy rodzicielskie, cit., s. 66 zwraca również uwagę na badania L. BENDER (Psychopatic behavior disorders in children, [w:] Handbook of correctional psychology, R.W. Linder, R.V. SELIGer, New York 1947), która wykazała związek 
unormowaniu odpowiedzialności osób zobowiązanych do nadzoru, ponieważ badania psychiatryczne dziecka mogą w tym przypadku przemawiać za wyłączeniem jego odpowiedzialności na zasadzie winy, zaś osobami, które spowodowały ten stan będą jego rodzice ${ }^{40}$.

Postawy rodzicielskie polegające na nadmiernej koncentracji na dziecku będą wywoływać skutki o charakterze nerwicowym. Postawa nadmiernie chroniąca może wywoływać opóźnienie dojrzałości emocjonalnej, infantylizm, opóźnienie dojrzałości społecznej, bierność, brak inicjatywy, poczucie większej wartości, zarozumialstwo, awanturniczość, egoizm. Natomiast postawa nadmiernego wymagania prowadzi do braku wiary we własne siły, niepewności, lękliwości, obsesji, pobudliwości, braku zdolności koncentracji, trudności w nauce w szkole i w przystosowaniu społecznym ${ }^{41}$.

Można również wskazać szereg potrzeb psychospołecznych dziecka, których niezaspokojenie może prowadzić do zaburzeń w zachowaniu, a po jakimś czasie - do trwałych ujemnych rysów osobowości. Należą do nich przede wszystkim: potrzeba miłości, życzliwości i ciepła uczuć, częsty kontakt z dzieckiem, potrzeba samourzeczywistnienia (realizacji własnych uzdolnień i zamierzeń) i potrzeba szacunku ${ }^{42}$.

Sposób wychowywania dzieci przez ich rodziców bywa też określany mianem „stylu rodzicielskiego”. Można wskazać na typologię opartą na podstawie dwóch czynników - poziomie ciepła rodzicielskiego (wsparcia, czułości) oraz kontroli rodzicielskiej (stopnia monitorowania i dyscyplinowania dziecka), których natężenie okre-

między wczesnym zerwaniem więzów uczuciowych, a psychopatią. oraz S. GLUECK i E. Glueck (Unreaveling juvenile delinquency, Cambridge 1950), którzy porównując grupy chłopców ze środowisk przestępczych i nieprzestępczych, stwierdzili, iż u tych pierwszych występował brak więzów uczuciowych w środowiskach rodzinnych.

${ }^{40}$ Por. art. 427 k.c. mówiący o odpowiedzialności osób zobowiązanych do nadzoru w sytuacji, gdy samemu sprawcy szkody winy poczytać nie można.

${ }^{41}$ M. ZiEMSKa, Postawy rodzicielskie, cit., s. 67.

${ }^{42}$ M. ZIEMSKA, Rola postaw rodzicielskich $w$ zaspokajaniu potrzeb psychicznych dzieci, [w:] Funkcjonowanie rodziny a problemy profilaktyki społecznej i resocjalizacji, M. ZiEMSKA, A. KwAK (red.), Warszawa 1982, s. 12-13. 
śla rodzaj stylu rodzicielskiego ${ }^{43}$. I tak, jako pozytywnie oddziałujący na dziecko wyróżnia się wariant, w którym rodzice wykazują wysoki stopień zarówno ciepła, jak i kontroli nad dzieckiem (rodzice autorytatywni). W przypadku niskiego poziomu ciepła (czułości) i wysokiego poziomu kontroli (rodzice autokratyczni) u dzieci może występować irytacja, zmienność nastroju, agresja i problemy z zachowaniem. Do podobnych skutków u dzieci (impulsywności, niedojrzałości) może prowadzić sytuacja odwrotna, w której rodzice, obdarzając dziecko dużą dozą ciepła, jednocześnie zaniedbują aspekt kontroli (rodzice permisywni). Wreszcie możliwy jest wariant, w którym oba czynniki, a więc ciepło i kontrola pozostają na niskim poziomie (rodzice obojętni), co wywołuje problemy w rozwoju społecznym dziecka i nieposłuszeństwo ${ }^{44}$.

M. Jacuńska zaproponowała charakterystykę stylów rodzicielskich przez wyodrębnienie w nich takich czynników jak: stosunek emocjonalny do dziecka, stawiane mu wymagania, kontrola oraz wzmocnienia (nagrody i kary) ${ }^{45}$. Poddanie analizie każdego z wyróżnionych elementów pozwala na określenie optymalnego stylu rodzicielskiego, oraz stylów niepożądanych, wraz z towarzyszącymi im, negatywnymi konsekwencjami w zachowaniu dziecka ${ }^{46}$.

W opracowaniach naukowych, których przedmiotem są omawiane zagadnienia, można również spotkać się z opisem i typizacją systemów wychowania w rodzinie. Wśród nich, jako mogące wywierać niekorzystny wpływ na rozwój dziecka, wymienić można wychowa-

${ }^{43}$ R. Vasta, M. M. Haiti, S.A. Miller, op. cit., s. 481. Wydaje się, iż prezentowany tu model wykazuje pewne podobieństwo do scharakteryzowanego wyżej modelu E. S. Schaefera.

${ }^{44}$ R. VAsta, M. M. Haiti, S.A. Miller, op. cit., s. 481-483.

${ }^{45}$ M. JACUŃSKA, Wychowanie matego dziecka $w$ rodzinie, [w:] Rodzina i dziecko M. ZIEMSKA (red.), cit., s. 350-351.

${ }^{46}$ M. JACUŃSKA, op. cit., s. 352-358 analizuje konsekwencje przyjęcia przez rodziców określonych stylów wychowawczych w ramach wyróżnionych czynników i wskazuje na możliwe zagrożenia. Warto podkreślić, że analiza ta prowadzona jest $\mathrm{w}$ ramach poszczególnych etapów rozwoju dziecka. Ponieważ wnioski autorki są zbieżne z innymi prezentowanymi tu badaniami, nie zostały szczegółowo przytoczone w tym miejscu. 
nie autokratyczne, stwarzające nadmierny dystans między rodzicami a dzieckiem i powodujące formalny stosunek do innych ludzi, a więc nie liczenie się przez dziecko z niczym, poza sztywnym zakazem ${ }^{47}$. Wyróżnić można również wychowanie liberalne, polegające na przyznaniu dziecku nadmiernej swobody, związane często z brakiem zainteresowania dzieckiem, bądź brakiem odpowiedzialności za nie, powodujące trudności z samodzielnym określeniem przez dziecko zasad postępowania i reguł moralnych ${ }^{48}$. Wskazuje się wreszcie na model wychowania okazjonalnego, charakteryzującego się podejmowaniem doraźnych działań wychowawczych, nie popartych wpajaniem norm postępowania. Skutkiem takich działań rodziców jest zachwianie poczucia bezpieczeństwa u dziecka, a w konsekwencji wzrost reakcji agresywnych dzieci w stosunku do otoczenia (zwłaszcza rówieśników) ${ }^{49}$. Jest oczywiste, iż takie sytuacje mogą być przyczyną wyrządzenia przez dziecko szkody, za którą odpowiedzialnymi, bądź przynajmniej współodpowiedzialnymi winni być rodzice dziecka.

Niezwykle istotnym problemem jest wskazanie konkretnych determinantów niewłaściwych postaw dziecka, w szczególności jego agresji. Wśród czynników biologicznych wyróżnia się wpływ hormonów na zachowanie dziecka. Stwierdzono na przykład współzależność między poziomem testosteronu u chłopców a poziomem ich agre$\mathrm{sji}^{50}$. Z uwagi na przedmiot niniejszego opracowania należy zwrócić szczególną uwagę na społeczne i środowiskowe determinanty agresji. $\mathrm{Z}$ przeprowadzonych badań wynika, iż istnieje związek między agresją rodziców - w szczególności w obrębie stosowanych przez nich środków wychowawczych, takich jak np. fizyczne karcenie - a agre-

\footnotetext{
${ }^{47}$ G. MAKIEŁŁO-JARŻA, op. cit., s. 313.

${ }^{48}$ G. MAKIEŁŁO-JARŻA, op. cit., s. 313.

${ }^{49}$ G. MAKIEŁŁO-JARŻA, op. cit., s. 314.

${ }^{50}$ R. VAsta, M. M. Haiti, S.A. Miller, op. cit., s. 563. Należy jednak zaznaczyć, iż mechanizm wpływu hormonów na zachowanie nie jest w pełni wyjaśniony, a ich wysoki poziom może również wynikać z wpływów środowiskowych, np. rodzaju podejmowanych przez chłopców zabaw. Por. R. Vasta, M. M. Haiti, S.A. Miller, op. cit., s. 563.
} 
sją ich dziecis ${ }^{51}$. Na korelację tę może wpływać modelowanie zachowań agresywnych dzieci, które naśladują zachowania swoich rodziców, oraz tzw. ,proces zniewalania rodzinnego" 52 oznaczający występującą w niektórych rodzinach metodę wzajemnej kontroli poprzez agresję i inne środki przymusu, a więc przewagę reakcji negatywnych i wrogich nad pozytywnymi, polegającymi na zachęcaniu do odpowiedniego zachowania. Mechanizm ten przejawia się w występowaniu kłótni i eskalacji konfliktu w sytuacji, gdy odpowiedzią na zachowanie agresywne jest zachowanie jeszcze bardziej agresywne. W takich warunkach stosowanie agresji staje się metodą realizacji potrzeb i wpływania na pozostałych członków rodziny ${ }^{53}$. Przedmiotem zainteresowania badaczy jest również wpływ przemocy, z którą dzieci stykają się w mediach elektronicznych, na poziom ich agresji. Należy podkreślić, że za ten element wychowania również odpowiadają rodzice, którzy powinni sprawować kontrolę nad korzystaniem przez ich dzieci z mediów elektronicznych. Jakkolwiek uchwycenie korelacji między przekazem mediów a zachowaniem dziecka jest trudne od strony metodologicznej badań ${ }^{54}$, to jednak zdecydowanie przeważa w tej mierze pogląd o negatywnym wpływie przemocy w mediach elektronicznych na zachowanie dzieci ${ }^{55}$. Najczęstszym zjawiskiem jest bezpośrednie naśladowanie zachowań obserwowanych przez dzieci np. w telewizji. Badania przemawiaja jednak również na rzecz tezy, iż przekaz agresji w mediach elektronicznych wywołuje także inne formy agresji u dzieci i to w perspektywie długoterminowej. Dzieje się tak na przykład poprzez zwiększanie u dzieci tolerancji na agresję przekazem mediów,

${ }^{51}$ R. Vasta, M. M. Haiti, S.A. Miller, op. cit., s. 566.

${ }^{52}$ Szerzej na temat definicji i badań nad tym zjawiskiem por. R. VASTA, M.M. HAITI, S.A. Miller, op. cit., s. 563.

${ }^{53}$ R. Vasta, M. M. Haiti, S.A. Miller, op. cit. s. 563.

${ }^{54}$ Trudność polega na poddaniu badaniom porównawczym grup dzieci, wychowujących się w identycznych warunkach, a różnych jedynie pod względem wpływu mediów elektronicznych.

${ }^{55}$ R. Vasta, M. M. Haiti, S.A. Miller, op. cit., s. 567 powołują szereg raportów i opracowań na poparcie tej tezy. 
oraz wyzwalanie pewnego rodzaju uzależnienia (dzieci u których wyzwolono agresję pragną kontaktu z większą jej ilością) ${ }^{56}$. W opracowaniach naukowych podkreśla się znaczenie zjawiska naśladownictwa u dzieci, co prowadzi do wniosku, iż od jakości wzorów osobowych prezentowanych przez rodziców zależy utrwalanie właściwych postaw u dzieci ${ }^{57}$. Ilustrację tego zjawiska stanowią eksperymenty prowadzone wśród dzieci w wieku przedszkolnym, którym ukazywano model agresywnego zachowania (biorąca udział w eksperymencie osoba dorosła zachowywała się agresywnie w stosunku do zabawek) i zaobserwowano przenoszenie tego wzorca na zachowanie dziecka względem swoich rówieśników ${ }^{58}$. Powyższe ustalenia mają istotne znaczenie dla problemu odpowiedzialności rodziców za szkodę wyrządzoną przez ich dziecko również wtedy, gdy obserwuje ono konflikt między rozwodzącymi się rodzicami.

Interesujące studium dotyczące przyczyn agresji u dzieci przedstawiła I. Obuchowska ${ }^{59}$. Doświadczenia dziecka, które mogą być źródłem agresji, autorka podzieliła na emocjonalne, poznawcze oraz socjalizacyjne. Pierwsze $z$ nich oddziałują negatywnie na rozwój dziecka wtedy, gdy polegają na zaburzeniu więzi emocjonalnej z rodzicami. Ilustrując ten mechanizm autorka powołała się na badania

${ }^{56}$ L.R. Huesmann, K. Lagerspetz, L.D. Eron, Intervening variables in the television violence-agrression relation: Evidence from two countries, «Development Psychology» 20 (1984), 746-775.

${ }^{57}$ Problem jest oczywiście poddany bardziej szczegółowej analizie, w której wyróżnia się poszczególne rodzaje naśladownictwa u dzieci (bezpośrednie, odroczone) oraz bada biologiczne uwarunkowania tego procesu. Por. G. MAKIEŁŁo-JARŻA, op. cit., s. $375-377$.

${ }^{58}$ G. MaKIelto-JaRŻA, op. cit., s. 378.

${ }^{59}$ I. OвuchowsKa, Agresja dzieci w perspektywie rozwojowej, [w:] Agresja i przemoc a zdrowie psychiczne, M. BINCZYCKA-ANHolcer (red.), Warszawa-Poznań 2001, s. 45 i n. poprzedziła swoje rozważania na temat przyczyn agresji u dzieci precyzyjnym zdefiniowaniem pojęcia agresji, na którą składają się następujące czynniki: 1) bezpośrednie lub pośrednie powodowanie szkody, 2) intencjonalność działania, 3) społeczna ocena zachowania jako przeciwnego w stosunku do zachowania prospołecznego. 
M. Grackiej-Tomaszewskiej ${ }^{60}$ i wskazała na następujący mechanizm: niechęć matki do dziecka wywołuje u niego poczucie lęku, to zaś przekształca się w agresję. Przytoczyła również badania J. LeDoux'a z 2000 r. ${ }^{61}$, wskazujące na istnienie ,pamięci emocjonalnej przedwerbalnej", która wiąże najwcześniejsze doświadczenia dziecka z jego zachowaniem w późniejszym życiu. Wśród poznawczych determinantów agresji zostały wskazane surowe metody wychowawcze (w tym kary cielesne), prowadzące do ukształtowania u dziecka ,autorytarnej struktury umysłu”, sprzyjającej dyskryminowaniu innych osób i stosowaniu przemocy ${ }^{62}$. Doświadczenia socjalizujące obejmują wzory kulturowe i inne różnorodne wpływy oddziaływujące na dziecko. Wśród nich można wymienić np. filmy, programy telewizyjne czy też gry komputerowe, które mogą być naśladowane przez dzieci i obniżają ich wrażliwość na agresję ${ }^{63}$.

Również zdaniem H. Liberskiej i M. Matuszewskiej podstawowymi źródłami zaburzeń w rozwoju dziecka, przejawiającymi się w jego zwiększonej agresywności jest długotrwała frustracja wynikająca z rozpadu więzi emocjonalnej $\mathrm{z}$ rodzicami oraz naśladowanie obecnych w rodzinie osób przejawiających agresję ${ }^{64}$. Autorki nawiązały również do przedstawionej wyżej typologii postaw rodzicielskich M. Ziemskiej wskazując, że źródłem agresji dziecka mogą być zarówno postawy rodzicielskie pozbawione agresji, tj. postawa odtrącająca i unikająca (ze względu na wyzwalający frustrację deficyt emocjonalny), jak i te, które polegają na nadmiernej koncentracji na dziecku, a więc postawa

${ }^{60}$ M. GrackA-TomaszewsKa, Małe dziecko często chorujace - jego psychiczna reprezentacja u matki, rozprawa doktorska pod kier. M. Zalewskiej, Wydział Psychologii UW 1999 (praca niepublikowana znajduje się w bibliotece Wydziału Psychologii UW.)

${ }^{61}$ J. LeDoux, Mózg emocjonalny, Poznań 1999 r., s. 209 i n.

${ }^{62}$ I. OBuchowsKa, op. cit., s. 51.

${ }^{63}$ I. OBuchowsKa, op. cit., s. 52.

${ }^{64}$ H. LiBersska, M. MatuszewsKa, Wybrane czynniki i mechanizmy powstawania agresji wrodzinie, [w:] Agresja iprzemocazdrowiepsychiczne, M. BINCZYCKA-ANHOLCER (red.), cit., s. 82-83. 
nadmiernie wymagająca (np. poprzez modelowanie agresji stosowaniem dotkliwych kar fizycznych lub wyzwolenie kompleksów dziecka) i nadmiernie chroniąca (poprzez wyłączenie mechanizmu samokontroli emocjonalnej dziecka $)^{65}$. Warto podkreślić, że autorki - powołując się na badania własne - wskazują postawę nadmiernie chroniąca, jako szczególnie niekorzystną z omawianego punktu widzenia ${ }^{66}$.

W badaniach K. Barłóg ${ }^{67}$, przeprowadzonych wśród dzieci w wieku przedszkolnym, podjęto m.in. próbę uchwycenia zależności między ich agresywnymi zachowaniami, a takimi czynnikami jak: zaburzona struktura rodziny, niewłaściwa atmosfera domu rodzinnego, niewłaściwe style wychowawcze, występowanie w otoczeniu dziecka wzorców agresji czy stosowanie wobec niego kar cielesnych. Badania potwierdziły te korelacje. Najlepszą metodą ich scharakteryzowania będzie przytoczenie uzyskanych przez autorkę danych liczbowych. Tak np., porównując grupę dzieci agresywnych z nieagresywnymi, okazuje się, iż $\mathrm{w}$ tej pierwszej mniej niż połowa dzieci wychowywała się w rodzinach pełnych $(44,4 \%)$, podczas gdy dzieci nieagresywne w zdecydowanej większości $(83,3 \%)$ miały zapewnione takie środowisko rodzinne ${ }^{68}$. Konfliktowa sytuacja w rodzinie występowała w połowie przypadków dzieci agresywnych i zaledwie w 14,3\% dzieci nieagresywnych. Ponad połowa dzieci z pierwszej grupy była wychowywana W sposób autokratyczny $(61,1 \%)$, zaś z drugiej grupy - jedynie 19\% ${ }^{69}$. Aż 88,9\% dzieci agresywnych było świadkami agresji w rodzinie, podczas gdy odsetek ten w przypadku dzieci nieagresywnych wynosił $31 \%$, a dzieci miały kontakt z zachowaniami agresywnymi o mniejszym na-

${ }^{65}$ Por. H. Liberska, M. Matuszewska, op. cit., s. 84-86, zwłaszcza zaprezentowaną tam szczegółową analizę psychologiczną konsekwencji poszczególnych niewłaściwych postaw rodzicielskich.

${ }^{66}$ H. Liberska, M. Matuszewska, op. cit., s. 87.

${ }^{67} \mathrm{~K}$. BARŁóG, Analiza zachowań agresywnych dzieci $w$ wieku przedszkolnym a ich środowisko rodzinne [w:] M. BINCZYCKA-ANHOLCER (red.), cit., s. 115-127.

${ }^{68}$ K. BARŁóG, op. cit., s. 121.

${ }^{69}$ K. BARŁÓG, op. cit., s. 121. 
sileniu $^{70}$. Na kontakt z przemocą w telewizji narażone były wszystkie dzieci zaliczone do grupy dzieci agresywnych i połowa dzieci nieagresywnych $^{71}$. Kary cielesne stosowano w stosunku do $77,8 \%$ dzieci agresywnych, natomiast nie stwierdzono ich stosowania w grupie dzieci nieagresywnych ${ }^{72}$. Przytoczone dane pozwoliły autorce badań w pełni potwierdzić hipotezę, iż agresywne zachowanie dziecka w znacznym stopniu jest uzależnione od rodzaju środowiska rodzinnego ${ }^{73}$.

W swoich badaniach, prowadzonych na grupie 90-ciu rodzin, M. Ziemska analizowała również korelacje między problemami wychowawczymi dzieci, a pożyciem jego rodziców ${ }^{74}$. Warto zwrócić uwagę, iż w rodzinach, których pożycie zostało określone jako harmonijne ${ }^{75}$, zaledwie około $20 \%$ dzieci stwarzało problemy. Zupełnie inaczej proporcje te przedstawiały się tam, gdzie małżeństwo rodziców przeżywało kryzys ( $66 \%$ dzieci) i wtedy, gdy związek małżeński rodziców został rozwiązany przez rozwód, bądź dziecko było wychowywane przez jednego rodzica na skutek śmierci drugiego (100\% badanych dzieci dotkniętych problemami wychowawczymi) ${ }^{76}$. W pełni potwierdza to tezę, iż rozbicie rodziny stwarza sprzyjające warunki do wykształcenia u dziecka postaw aspołecznych wtedy, gdy przebywa ono

${ }^{70}$ K. BARŁÓG, op. cit., s. 122.

${ }^{71}$ K. BARŁóG, op. cit., s. 121.

${ }^{72}$ K. BARŁóG, op. cit., s. s. 123; Warto jednak podkreślić, iż badania stosowania kar cielesnych nie przesądzają, co jest w tym przypadku przyczyną, a co skutkiem. Istnieje możliwość, iż agresja dzieci wyzwala u rodziców stosowanie najsurowszych środków wychowawczych. Uzyskane wyniki są jednak nad wyraz wymowne.

${ }^{73}$ K. BARŁóG, op. cit., s. 123.

${ }^{74}$ M. Ziemska, Postawy rodzicielskie, cit., s. 86.

${ }^{75}$ Chodziło w tym przypadku o zgodność między rodzicami i wzajemną akceptację przez nich postaw rodzicielskich (tzw. koalicję wychowawczą), nie zaś o prezentowanie przez nich właściwych postaw, por. M. ZIEMSKA, Postawy rodzicielskie, cit., s. 89.

${ }^{76}$ Warto jednak w tym miejscu zwrócić uwagę, iż w badaniach M. Ziemskiej, małżeństwa przeżywające kryzys i rozwiązane przez rozwód stanowiły nieliczną grupę badanych rodzin, co powoduje, iż podane liczby procentowe wyrażać moga jedynie ogólna tendencję, ze względu na zbyt małą próbę badawczą. 
w atmosferze napięcia i dysharmonii ${ }^{77}$. Jeżeli chodzi o stosowanie prawa, w kontekście powyższych ustaleń należałoby postulować, aby ustalenie winy rozkładu pożycia małżeńskiego w sprawie rozwodowej było brane pod uwagę $\mathrm{w}$ przypadku rozstrzygania odpowiedzialności odszkodowawczej rodziców za szkodę wyrządzoną przez ich dziecko.

W literaturze z zakresu psychologii wskazuje się, iż na wykolejenie bardziej jest narażona młodzież z rodzin, w których pożycie rodziców nie jest szczęśliwe ${ }^{78}$. Ponadto istnieje pogląd, iż harmonia w układzie wewnętrznych stosunków w rodzinie ma większe znaczenie dla prawidłowego rozwoju psychicznego dziecka niż równowaga emocjonalna rodziców ${ }^{79}$. Oznacza to, iż pewne niedostatki osobowości samych rodziców rekompensuje harmonia środowiska rodzinnego. Szczególnie szkodliwe i stwarzające ryzyko wykolejenia dziecka są takie przejawy dysharmonii w rodzinie, które przybierają postać jawnej agresji (kłótnie, wrogość, bójki) i są związane z postawą odtrącająca, bądź polegają na braku zaangażowania emocjonalnego rodziców i powiązane są z postawą unikającą względem dziecka ${ }^{80}$. Jak wskazała M. Ziemska: „Dysharmonia w rodzinie dostarcza dziecku wzorów agresji, niestałości, wrogości i aspołecznego zachowania." ${ }^{\text {. }}$.

Ustalono również wyraźną korelację między zachowaniami agresywnymi młodzieży, a zakłóceniem stosunków uczuciowych między rodzicami a dziećmi ${ }^{82}$. Jako czynnik potęgujący przejawianie postaw agresywnych wskazano jednoczesny konflikt uczuciowy między ojcem i synem i stosowanie przez ojca kar fizycznych ${ }^{83}$. Jak już wcześ-

${ }^{77}$ M. ZIEMSKa, Rodzina a osobowość, Warszawa 1975, s. 151.

${ }^{78}$ M. ZIEMSKA, Rodzina a osobowość, cit., s. 152.

${ }^{79}$ M. ZIEMSKa, Rodzina a osobowość, cit., s. 154.

${ }^{80}$ M. ZIEMSKA, Rodzina a osobowość, cit. s. 155.

${ }^{81}$ M. ZIEMSKA, Rodzina a osobowość, cit. s. 155.

${ }^{82}$ Por. w tym zakresie badania D. WóJcIK, Środowisko rodzinne a agresywność młodzieży, [w:] Funkcjonowanie rodziny a problemy profilaktyki społecznej i resocjalizacji M. ZIEMSKA, A. KWAK (red.), cit., s. 129-142 prowadzone na grupie 120 chłopców.

${ }^{83}$ D. WóJCIK, op. cit., s. 137. 
niej wspomniano, rola rodziców w zakresie kształtowania postaw agresywnych nie jest jednakowa, a mianowicie decydujące znaczenie posiada charakter kontaktów z ojcem, a mniejsze $-\mathrm{z}$ matką ${ }^{84}$. Zupełny brak kontaktu z ojcem może powodować zaburzenia w rozwoju dziecka, takie jak słabsze przystosowanie, lękliwość, wrogość w stosunku do otoczenia, agresję, brak identyfikacji z własną płcią ${ }^{85}$. Agresywność badanych chłopców wykazywała wyraźny związek z trzema grupami czynników, tj: prezentowaniem przez rodziców modelu agresji, przejawianiem przez nich tolerancji dla zachowań agresywnych dzieci oraz zaburzonymi kontaktami uczuciowymi dzieci $\mathrm{z}$ rodzicami ${ }^{86}$.

Nieumiejętne posługiwanie się systemem kar w sposób, który poniża dziecko, tłumi jego wrażliwość i pozostawia urazy psychiczne, może wyzwalać agresywność, brutalność i bezwzględność, wzbudzając u niego gniew, nienawiść, zawziętość i chęć zemsty ${ }^{87}$. Do takich kar należą: zawstydzanie dziecka, oziębłość, wyśmiewanie, poniżanie, kary cielesne. Kara spełnia swoją funkcję, gdy wyzwala poczucie winy z powodu popełnionego czynu, a zarazem budzi wiarę we własne siły, chęć zmiany zachowania i uczy odpowiedzialności ${ }^{88}$.

Warto również wskazać na problem skutków psychologicznych i behawioralnych, wywołanych przez teratogeny, a więc pozagenetyczne

${ }^{84}$ D. Wóscik, op. cit., s. 138. Badania prowadzone w rodzinach, w których matki zostały skazane na karę pozbawienia wolności wskazywały jednak na równie destrukcyjny wpływ na dziecko w takiej sytuacji. Por. L. MościckA, Diagnoza problemów opiekuńczo-wychowawczych $w$ rodzinach kobiet pozbawionych wolności [w:] Funkcjonowanie rodziny a problemy profilaktyki społecznej $i$ resocjalizacji M. ZIEMSKA, A. KWAK (red.), cit., s.160.

${ }^{85}$ Por. D. WóscıK, op. cit., s. 131 i przywołane tam badania.

${ }^{86}$ Wymienione trzy grupy czynników zostały przez D. WóJcıK, op. cit., s. 141 wyróżnione na podstawie analizy dorobku naukowego w tym zakresie oraz - jako hipoteza badawcza - w pełni potwierdzone w przytoczonych badaniach.

${ }^{87}$ M. GrochocińsKI, Kultura pedagogiczna rodziców, [w:] Rodzina i dziecko M. ZiEMSKA (red.), cit., s. 328.

${ }^{88}$ M. GrochociŃsKi, op. cit., s. 328. 
czynniki wpływające niekorzystnie na rozwój embrionu i płodu. Jak powszechnie wiadomo, czynniki takie jak określone leki terapeutyczne, narkotyki, infekcje matki czy zagrożenia środowiskowe moga wywoływać uszkodzenia embrionu i płodu ${ }^{89}$. Okazuje się jednak również, iż teratogeny mogą wywoływać skutki behawioralne nawet wtedy, gdy brak jest fizycznych zaburzeń rozwoju dziecka, z czego może wynikać wniosek, iż sfera rozwoju psychicznego dziecka jest najbardziej wrażliwa na tego rodzaju bodźce ${ }^{90}$.

Podkreślenia wymagają również konsekwencje maltretowania fizycznego i psychicznego dzieci oraz ich zaniedbywania, polegające na opóźnieniu w rozwoju społecznym dzieci i zwiększeniu ryzyka ich agresji ${ }^{91}$.

W dotychczasowych rozważaniach zostały przedstawione przede wszystkim czynniki oddziaływujące na dziecko w procesie jego wychowania w sposób negatywny, a więc zwiększający ryzyko wystąpienia zachowań mogących być źródłem szkody. Należy jednak również zwrócić uwagę na sposoby korzystnego oddziaływania na dziecko. Jest to istotne szczególnie w kontekście koncepcji uwzględniających wpływ biologicznych determinantów na zachowania dzieci, oraz stanowi dodatkowy argument na rzecz obciążenia rodziców odpowiedzialnością za działania ich dzieci. W jednym z badań udowodniono, iż zastosowanie odpowiednich metod treningowych modyfikujących metody wychowawcze rodziców, wpłynęło na wyraźną zmianę zachowań dzieci92. Możliwe jest również stosowanie odpowiednich technik w odniesieniu do dzieci. Jedna z nich polega na zastapieniu negatywnych emocji współwystępujących z agresją odczuciami przeciwnymi, takimi jak empatia do innych osób $^{93}$. Innym sposobem jest nauczanie dziecka odpowiednich strate-

\footnotetext{
${ }^{89}$ R. Vasta, M. M. Haiti, S.A. Miller, op. cit., s. 137.

${ }^{90}$ R. Vasta, M. M. Haiti, S.A. Miller, op. cit., s. 136 i n.

${ }^{91}$ R. Vasta, M. M. Haiti, S.A. Miller, op. cit., s. 487.

92 R. Vasta, M. M. Haiti, S.A. Miller, op. cit., s. 570.
}

${ }^{93}$ Metoda ta powstała przy uwzględnieniu założenia, iż proces poznawczy u dziecka agresywnego może przebiegać w sposób odbiegający od normy. Dziecko pozbawione empatii inaczej odczytuje sytuację, w której się znalazło i łatwiej reaguje agresją. 
gii postępowania i realizacji ich w codziennym życiu" ${ }^{94}$ Tzw. „trening atrybucyjny" polega na nauczeniu dziecka właściwego odczytywania intencji innych osób, gdyż - jak się okazuje - u podstaw postaw agresywnych może stać zaburzona umiejętność odczytywania i interpretowania sytuacji, w której dziecko się znalazło ${ }^{95}$. K. Barłóg, omawiając wyniki przedstawionych wyżej badań, podaje szereg metod przeciwdziałania agresji, takich jak: modelowanie zachowań nieagresywnych, ćwiczenie umiejętności pokojowego rozwiązywania konfliktów, ćwiczenie kompetencji komunikacyjnych i umiejętności prowadzenia negocjacji, sprzyjanie i rozwijanie empatii ${ }^{96}$. Wśród czynników pozytywnie oddziałujących na rozwój dziecka pozostają oczywiście - nie omówione tutaj szczegółowo - właściwe postawy i style rodzicielskie. Należy również wspomnieć o obowiązkach rodziców, które powstają w przypadku rozpoznania u dziecka określonych zaburzeń, np. zespołu nadpobudliwości psychoruchowej (ADHD) ${ }^{97}$. Konieczne jest w takich przypadkach objęcie dziecka odpowiednią terapią. Podejmowanie wszystkich tego typu działań stanowi obowiązek rodziców wtedy, gdy są one niezbędne do właściwego wychowania dziecka, a ich zaniechanie może być oceniane jako zawinione przez rodziców, a więc decydować o ich odpowiedzialności cywilnoprawnej.

Powyższe rozważania w aspekcie psychologicznym mają charakter przekrojowy i oczywiście nie wyczerpują poruszonego problemu. Dostarczaja jednak istotnych przesłanek dla interpretacji unormowania cywilnej odpowiedzialności rodziców za szkodę wyrządzoną przez dziecko.

Przedstawione poglądy i wyniki badań potwierdzają w pełni tezę, iż zaniedbania rodziców w procesie wychowania prowadzą do zabu-

Szerzej na ten temat por. R. Vasta, M. M. Haiti, S.A. Miller, op. cit., s. 570.

${ }^{94}$ R. Vasta, M. M. Haiti, S.A. Miller, op. cit., s. 570.

${ }^{95}$ Por. R. Vasta, M. M. Haiti, S.A. Miller, op. cit., s. 571 i n., w szczególności opis przeprowadzonego programu badawczego.

${ }^{96}$ K. BARŁÓG, op. cit., s. 124-125.

${ }^{97}$ Podstawowe informacje na ten temat można uzyskać w Internecie pod adresem: http://www.adhd.info.pl/index.php?page=main/abcwiedzy.php 
rzeń rozwoju dziecka. Tak sformułowana implikacja nie może być na gruncie zasad wnioskowania dedukcyjnego - odwrócona, to znaczy nie można ze stuprocentową pewnością stwierdzić, iż każdy przypadek zawinionego wyrządzenia szkody przez dziecko wynika z błędów wychowawczych jego rodziców. Twierdzenie takie zostało jednak w znacznym stopniu uprawdopodobnione, a więc jest możliwe do zaaprobowania na gruncie wnioskowania indukcyjnego, co oznacza, iż można przyjmować z dużym prawdopodobieństwem, że dziecko powodujące szkodę zostało zaniedbane przez rodziców. Najbardziej wymowne są tutaj wyniki przytoczonych wyżej badań M. Ziemskiejes, według których $100 \%$ badanych dzieci rozwiedzionych rodziców stwarzało problemy wychowawcze. Powyżej został również poruszony problem oceny oddziaływania na rozwój psychiczny dziecka czynników o charakterze środowiskowym i genetycznym. O ile wpływ tych pierwszych jest niewatpliwy i udowodniony licznymi badaniami, o tyle znaczenie determinantów genetycznych $-\mathrm{z}$ wyjątkiem zdiagnozowanych chorób genetycznych - pozostaje w sferze badań ${ }^{99}$, przy czym skutki przez nie wywoływane również zależne są od czynników środowiskowych ${ }^{100}$. Wśród nich należy wymienić zwłaszcza prezentowane przez rodziców postawy rodzicielskie, ewentualnie odpowiednią terapię czy omówione wyżej metody treningu, które stanowią obowiązek osób wychowujących dziecko.

Podsumowując zebrany materiał można stwierdzić, iż każdy rodzaj wychowawczego oddziaływania rodziców na dziecko wywiera na nie wpływ, możliwy do określenia metodami naukowymi. Nawet wtedy, gdy np. prezentowane typologie postaw rodzicielskich są względem siebie konkurencyjne, możliwe jest uchwycenie zbieżności w zakresie powiązania określonych postaw rodziców z ich skutkami. Autorzy pozostają zgodni, iż odtrącenie dziecka przez rodziców i nadmierny dystans uczuciowy w stosunku do dziecka ma dla jego oso-

${ }^{98}$ M. Ziemska, Postawy rodzicielskie, cit., s. 86 i n.

${ }^{99}$ Należałoby w tym zakresie np. wyodrębnić gen odpowiedzialny za skłonność do agresji. Por w tym zakresie P.G. ZimBARDO, op. cit., s.150 i n.

${ }^{100}$ P.G. ZiMBARDO, op. cit., s. 150-151. 
bowości szczególnie destrukcyjne znaczenie. Teza ta warta jest szczególnego podkreślenia, gdyż z sytuacją taką mamy do czynienia nie tylko w przypadku niewydolności wychowawczej rodziców wykonujących władzę rodzicielską i pozostających w związku małżeńskim. Rozwód rodziców, ich separacja, wychowywanie się dziecka w rodzinie niepełnej bądź patologicznej może być przez nie odbierane w taki właśnie sposób. Z prezentowanej wiedzy z zakresu psychologii wynika również ewidentny związek agresji dzieci z czynnikami modelującymi ją, takimi jak niewłaściwe wzorce osobowe czy przekaz mediów elektronicznych (telewizji, gier komputerowych itp.).

Poczynione spostrzeżenia nie mogą pozostać bez wpływu na interpretację przepisów normujących odpowiedzialność rodziców za szkodę wyrządzoną przez ich dziecko. Na gruncie obecnie obowiązującego prawa odpowiedzialność ta wynika z art. 415 k.c., który wymaga udowodnienia związku przyczynowego między działaniem sprawcy szkody a samą szkodą i jego winy, bądź też z art. 427 k.c., który stwarza łatwiejszą perspektywę uzyskania odszkodowania przez osobę poszkodowaną dzięki przerzuceniu ciężaru dowodu braku winy w nadzorze na osobę ten nadzór wykonująca. Druga z wymienionych konstrukcji prawnych odpowiada doświadczeniu życiowemu, ponieważ sam fakt wyrządzenia szkody przez dziecko świadczy najczęściej o braku nadzoru bądź jego wadliwym wykonywaniu. Przytoczone wyżej wyniki badań psychologicznych przemawiają na rzecz takiego rozwiązania, ponieważ wyraźnie wskazują na istnienie związku przyczynowego między zachowaniem dziecka a działaniem lub zaniechaniem jego rodziców. Tym samym mogą posłużyć jako uzasadnienie zastosowania „ostrzejszego” dla rodziców reżimu odpowiedzialności cywilnej, tj. art. 427 k.c. Szersza interpretacja pojęcia ,nadzoru”, obejmująca wychowanie dziecka, uzasadnia koncepcję polepszenia sytuacji osoby poszkodowanej, ponadto jest bardziej funkcjonalna, a przede wszystkim harmonizuje z prezentowanymi w niniejszym opracowaniu wynikami badań. W efekcie potwierdza to słuszność motywów wprowadzenia do kodeksu cywilnego określonej koncepcji unormowania odpowiedzialności cywilnej rodziców za szkodę wyrządzoną przez ich dziecko. Tylko takie ujęcie tej odpowiedzialności pozwoli w praktyce uzyskać odszkodowanie również 
od tego z rodziców, który nie wykonuje bieżącej pieczy nad dzieckiem, np. w razie rozwodu rodziców. Szersze omówienie tego zagadnienia w aspekcie prawnym wykracza poza ramy niniejszego opracowania.

\section{Psychological Considerations of the Behavior of Children Causing a Damage and Parents' Liability FOR SUPERVISION}

\section{Summary}

The study concerns the problem of parents' compensatory liability for a damage caused by their children in a psychological perspective.

The author presents basic issues being the subject of the studies on children's psychology and refers them to the problem of parents' civil liability for damages caused by their children. First the paper discusses results of the selected researches concerning the relation between the development of a child and his experiences from the early childhood. Then the author introduces scientific typology of so called parental attitudes, parental styles and systems of family upbringing. and afterwards analyses the reasons for children's aggressive attitudes.

The performed analysis enabled the author to draw conclusions related to the application of the law. They concern wide range of liability for child complying not only care but also children's upbringing. 